\title{
„LEGYEN A MATEMATIKA MINDENKIÉ!" \\ 25 ÉVE HALT MEG VARGA TAMÁS
}

\section{Neményi Eszter}

Eötvös Loránd Tudományegyetem

„Látszólag csak az egyszeregy tanításáról van szó, valójában nagyobb ügyről. Arról, hogy közkinccsé válhat-e, válik-e a matematika. Minthogy most nem az. Sokan azonban úgy véljük szerte a világban, hogy azzá válhat, és azon dolgozunk - megosztva ötleteinket, pozitív és negatív tapasztalatainkat -, hogy váljon is, mihamarabb” - olvasom a Kritika 1987. decemberi számában „Az egyszeregy körül” címü írás bevezető sorait. Az üzenet szerzője: Varga Tamás.

Én őt 1967-ben ismertem meg, még az ELTE-n. Vele kapcsolatban valami „új” módszerről lehetett hallani. Kíváncsiságból elmentem megnézni a Váci utcában rendezett bemutatót. Gizi néninél is, Lidi néninél is láttam egy-egy órát ${ }^{1}$, és aztán nem tudtam szabadulni az élménytől! Lehet így is tanítani a matematikát? Hogy minden kisgyerek örömmel dolgozik? Hogy az óra végén nem akarják meghallani a csengetést? És hogy egy-egy feladatnak többféle megoldását látják meg a 9-10 évesek, és sokkal gyorsabban, mint én, a negyedéves matematika szakos egyetemi hallgató? Azt aztán csak lassan, hosszú idő alatt értettem meg igazán, hogy milyen egységes, átgondolt koncepció alapján jött létre ez a csoda.

Fent idézett írása nyomán - amit már halála után kaptunk meg -, Rá emlékezve most néhány számomra fontos gondolatot szeretnék kiemelni.

Az egyik, hogy miképpen gondolkodott a matematikáról, mi volt számára a matematika.

A másik, hogy hogyan gondolkodott a matematikatanitásról, a matematikai nevelésröl. Miben kívánt egészen mást, mint ahogyan addig volt e téren?

\section{Mi volt számára a matematika?}

Idézett cikkében írja: „A matematika a legalsó szinttől a legfelsőig tapasztalatokból nő ki: próbálkozásokból, sejtésekből és ellenőrzésükből, elvetésükből vagy megerösítésükből. Mégis az emberi szellem szabad alkotása. Híd a »két kultúra között. Tele van játékossággal, esztétikummal: müvészet is."

Számára a matematika lényegéhez tartozott, hogy a valóságos környezet tulajdonságait, a valóságos dolgok összefüggéseit, viszonyait ragadja meg a maga eszközeivel. A valóságos problémákat írja le a saját nyelvén, saját modelljeivel, és ezek felhasználásával oldja meg amazokat. Így valamiképpen alapja, eszköze a fizikának, technikának, egyéb tudományoknak.

De nem kisebb fontosságot tulajdonított annak, hogy a matematika $a z$ emberi szellem szabad alkotása, müvészet is.

Tanítási gyakorlatában és 1963-ban elindított komplex matematikatanítási kísérletében egyaránt arra törekedett, hogy a kisdiákok is átélhessék a

\footnotetext{
${ }^{1}$ Tiszai Zoltánné, Gizi néni és Barabás Lajosné Lidi néni
} 
matematikával való foglalkozásnak ezt a teljességét: az ismeretek tapasztalatokon nyugvó birtokba vételét, a szellemi alkotás gyönyörüségét, és művészi játékosságát, esztétikumát. Fontosnak tartotta, hogy a matematikával való foglalkozás minden korosztály számára örömszerző és alkotó tevékenység legyen.

Matematikai játékai sohasem öncélú szórakoztatások voltak. Nem írta lepkeszárnyakra az egyébként talán unalmas számolási feladatokat, de épített a megértés örömére, a felfedezés és a véletlen megélésének izgalmára, a „már én is tudom" megelégedésére.

Az óvodás Marika piros és sárga utat épített egymás mellett a színes rudakból. Megállapította, hogy a sárga út hosszabb.

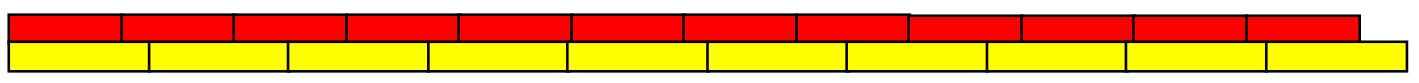

Ezután az óvónő kérdésére, hogy melyik több: a piros vagy a sárga rúd, a rudak párokba rendezésével kereste a választ:

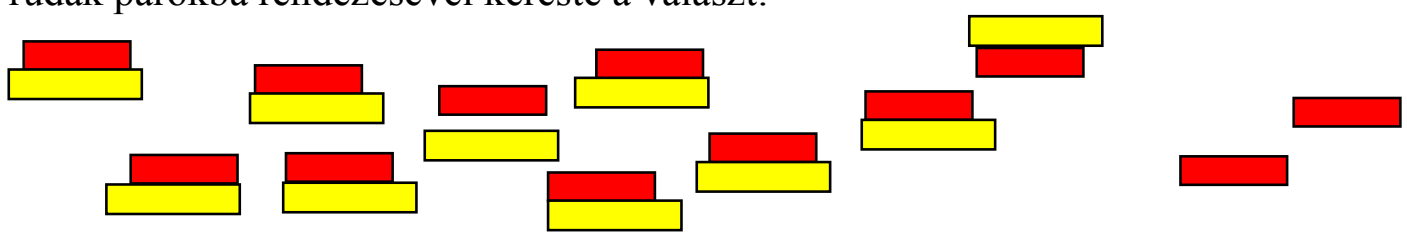

Kétkedést kifejezve kérdezte az óvónő: hát nem a sárga út volt hosszabb? Marika elbizonytalanodott, és újból megépítette az utakat. Magára hagyva megismételte a rudak párokba válogatását, aztán felkiáltott: „Jaj de buta vagyok! Hiszen a sárga rúd hosszabb!"

A „Jaj de buta” kislány csodálatos felfedezése - gondolom - mély megértés alapjává vált. $\mathrm{S}$ talán belőle lett az egyik tanuló, akinek később a mértékváltás nem okozott igazi problémát!

Amikor a téglalap területén dolgoztak a Váci utcai negyedikesek, sok különféle alakú és méretü, kivágott téglalapot hozott Varga Tamás a gyerekeknek, és mindenki kapott sok-sok egybevágó kis négyzetlapot, hogy fedje be velük a téglalapját. Állapítsa meg, hány ilyen lappal lehet befedni. Aki aztán egy téglalap lefedése után (vagy esetleg már az első egy-két sor kirakása után) tudta, mi lesz a kirakás eredménye, kérdezte: muszáj kirakni? Ha tudod anélkül is, akkor nem kell! - volt a válasz. Aztán elmagyarázhatta felismerését, előbb csak a tanító néninek, Tamás bácsinak, aztán - esetleg csak másnap, vagy egy hét múlva - a társainak is. És aki csak több téglalap lefedése után fedezte fel az azonos hosszú sorok szerepét, az is átélhette, hogy ,én tanultam meg", „én is tudom”!

Az egyik igen gyakran alkalmazott játék az ún. szabály-játék vagy gépjáték például a függvényszerü gondolkodás formálásának csodálatos eszköze lett, valamint tapasztalati bázis a függvényfogalom megalkotásához.

Jól képzett mérnök-szülők nehezményezték, hogy minek adunk olyan feladatokat a harmadikos, negyedikes gyereküknek, amit ök sem tudnak megoldani. Egy munkalapon ilyen feladványok szerepeltek egymás mellett: 

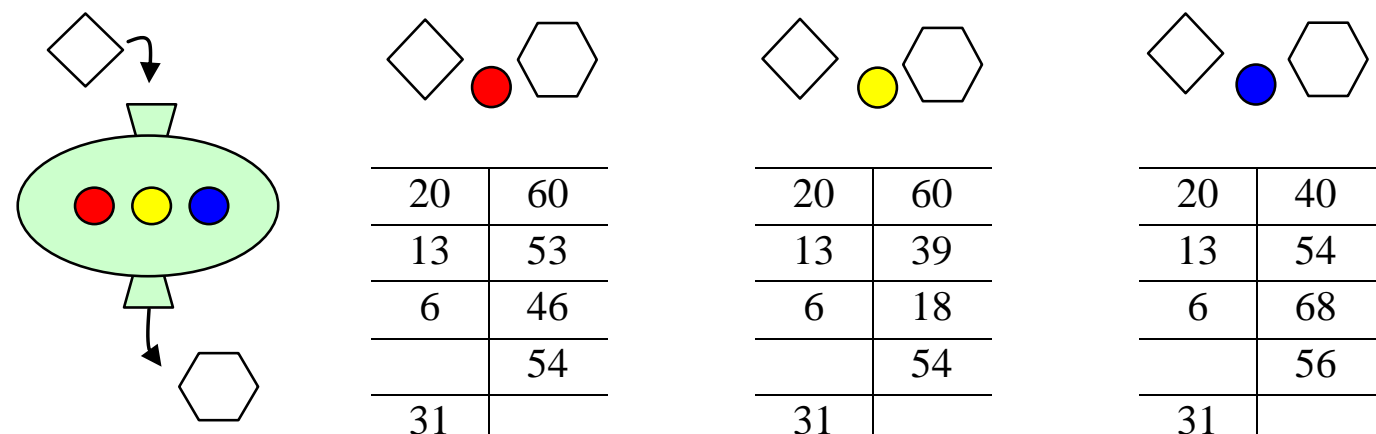

\begin{tabular}{c|c}
\hline 20 & 60 \\
\hline 13 & 53 \\
\hline 6 & 46 \\
\hline & 54 \\
\hline 31 & \\
\hline & 42 \\
\hline & \multicolumn{1}{|l}{}
\end{tabular}

\begin{tabular}{c|c}
\hline 20 & 60 \\
\hline 13 & 39 \\
\hline 6 & 18 \\
\hline & 54 \\
\hline 31 & \\
\hline & 42 \\
\hline & \multicolumn{1}{|l}{}
\end{tabular}

\begin{tabular}{c|c}
\hline 20 & 40 \\
\hline 13 & 54 \\
\hline 6 & 68 \\
\hline & 56 \\
\hline 31 & \\
\hline & 42 \\
\hline & \multicolumn{1}{|l}{}
\end{tabular}

Az első „bébikönnyü”: mindegyik számhoz hozzáad 40-et! A második talán még egyszerübb: megháromszorozza a bedobott számot. De a harmadiknak nincs semmi értelme! - mondták, írták sokan felháborodva.

Emlékszem, a Váci utcai 4. osztályosok micsoda izgalommal foglalkoztak hasonló feladványokkal. Aki „kitalálta”, hogy mi lehet a gép szabálya, amikor a kék gombot nyomjuk meg, csak Gizi néninek súgta meg, hogy ne vegye el mások örömét, hogy mások is kitalálhassák.

Varga Tamás meglátta és felhasználta az alkotás szerepét abban, hogy a kisgyerekek is valódi szellemi tevékenységet végezhessenek. Nemcsak végrehajtói voltak betanított munkásként a tanító utasításainak. Nemcsak elvégezték a kijelölt müveleteket, hanem a müveletek felhasználásával számokat alkottak. Igen egyszerü példája volt ennek az ún. staféta játék. Csapatonként egy-egy számot kaptak a gyerekek, s annak sokféle ,nevét” írták a táblára, egymásnak adva a staféta-krétát. Aztán közösen ellenőrizték és értékelték a csapatok munkáját.

Vagy kis kutatásokat végezhettek: miféle számokat lehet alkotni például a 3 és az 5 felhasználásával, ha csak összeadásokat végezhetnek velük? És miket nem tudnak így elöállítani?

Alkotó tevékenységek során ismerkedtek a gyerekek testekkel, síkidomokkal. Azokkal, amelyeket szabadon vagy valamilyen feltételekkel létrehoztak, meg azokkal, amelyek alkotóelemekként szolgáltak.

Például kézbe adott kockákból, színes rudakból építettek, szívószálakból füztek, síkidomokból ragasztottak össze különféle testeket kedvükre.

Aztán másoltak eléjük épített vagy rajzban megjelenített testeket, ennek során alakot, méretet, állást, irányt, illeszkedést tanulhattak megfigyelni.

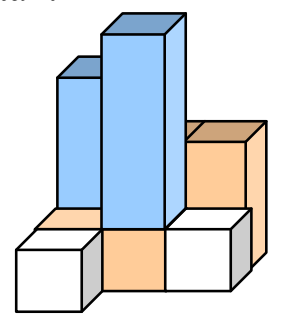

- Ilyen testekből - pl. 4 vagy 8 kockából, vagy 2 fehér, 3 rózsaszín és 2 világoskék rúdból - építhettek adott alaprajzon vagy szavakban megfogalmazott feltételek szerint: 
- téglatest legyen,

- kocka legyen,

- minél kevesebb papírral lehessen becsomagolni, vagy minél kevesebb festékkel bevonni;

- adott számú csúcsa legyen...

- Esetleg alkossák meg 4 kockából az összes lehetséges testet, ha egész lapjukkal kell összesimulniuk a kockáknak.
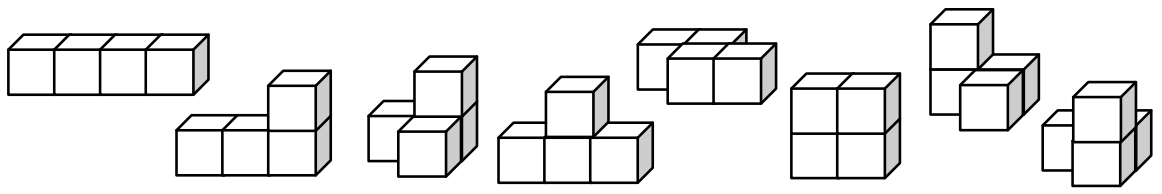

- De alkottak állitásokat, tárgyakról, összességekről, alakzatokról:

Például a 4 kockából megalkotott testekröl. (Van köztük téglatest; van olyan köztük, amelynek valamelyik lapja hatszög. Mindegyiknek vannak párhuzamos lapjai. Amelyik nem téglatest, azon van beugrás, azaz nem konvex...)

- Tulajdonságokhoz, állításokhoz létrehoztak összességeket, rendszereket:

Például a logikai lapokból hoztak létre összességeket olyan állítások szerint, hogy

- $\quad$ mindegyik lap piros

- minden piros benne van

- $\quad$ az előbbi mindkét állítás igaz

S ez utóbbi alapján eljutottak a részhalmaz meghatározó tulajdonságáig is.

- Készítettek sorozatokat, táblázatokat adott szabály szerint, vagy néhány adathoz, adatpárhoz, adathármashoz illeszkedőt

Például: folytasd a sorozatot!

$1,2,4 \ldots$

És sokféle szabály szerint alkottak más-más sorozatot:

$1,2,4,5,7,8,10 \ldots$

$1,2,4,7,11,16,22 \ldots$

$1,2,4,8,16,32,64 \ldots$

$1,2,4,7,12,20 \ldots$

és fogalmazták meg a követett szabályt.

- Alkottak akkor is, amikor valamely probléma értelmezéséhez, megoldásához kerestek, alkottak megfelelö modellt.

Például amikor arra keresték a választ, hogy egy papírcsík 10 összehajtása során hány rész keletkezik - sorozatot alkottak az alakuló részek száma szerint:

(1), 2, 4, 8... és így jutottak el a probléma megoldásához. 
- Sőt mondhatjuk, hogy a matematikai fogalmak megalkotásának is főszereplői és nem elszenvedői voltak. Sokáig szavakba öntés nélkül, aztán saját megnevezéssel, körüljárással, s talán csak a felső tagozat vége felé egyre szabatosabb definícióval.

Itt szeretnék áttérni arra a gondolatra, hogy hogyan is gondolkodott Varga Tamás a matematika tanulásáról, tanitásáról, a matematikai nevelésröl. Bár már eddig sem tudtam kikerülni egy-egy elemét.

A munkatársaival együtt kidolgozott tantervben a matematikával való foglalkozás legfóbb feladataként a gyerekek fejlesztését fogalmazta meg minden olyan területen, amelyet szolgálhat ez a tevékenység. A matematika segítségével fejleszteni kívánta a tanulókban a megértést, az ítélőképességet, az összefüggéslátást, de olyan általánosabb emberi képességeket is, mint pl. a figyelem, emlékezet, akarat, együttmüködés, egymás megértésére való törekvés, kommunikáció, önismeret, önellenőrzés. Emellett hangsúlyozta a matematikai ismeretek fontosságát, a készségek el nem hanyagolható szerepét is.

Igen nagy gondot fordított a tiszta fogalmak kimunkálására. Továbbképző munkájában, előadásaiban, írásaiban arra törekedett, hogy a pedagógusok pontosan értsék, mi az egyes fogalmak tartalma, hiszen csak így szolgálhatják a gyerekek fogalomépítését.

Példaként szeretném kiemelni a müveletfogalmakat. Az egy- és kétváltozós müveletek megkülönböztetését, aminek igen nagy szerepe van a müveleti tulajdonságok pontos értésében, használatában.

Lehet-e a kivonás szereplöit felcserélni? És lehet-e egy müveletsorban előforduló szereplők sorrendjét változtatni, ha ott kivonások is szerepelnek? Ha nincs tiszta fogalmunk, ha nem tisztán értelmezzük a kétféle műveletet, nincs olyan gyerek, aki megértené, mikor szabad csereberélni, és mikor nem!

P1. egyenlő-e a $6-2$ és a $2-6$ ? - Nem! A két változó szerepe más és más; nem cserélhető fel a kisebbítendő és a kivonandó!

És egyenlö-e a $17-2-3+8-9$ és a $17-9+8-3-2$ ? Igen. Miért is? A kiinduló számot egymás után növelik és csökkentik az egyváltozós műveletek, $\mathrm{s}$ az egyenrangú változtatások - mint pl. a hozzáadások és elvételek - sorrendje nem befolyásolja a teljes változás eredményét. Olyan ez a müveletsor, mintha több egybemenetü gépet kapcsolnánk egymáshoz: mindegyik változtatja valahogyan a beérkező adatot, de együtt ezek a változások - sorrendjüktől függetlenül - azonos eredményre vezetnek.

A szorzás sem csak kétváltozós müvelet-tartalmú! Sőt a mindennapi szituációk legtöbbje egyváltozós szorzás-fogalmat alkalmaz. Amikor adott darabszámot, adott mennyiséget többszörözünk, akkor egyváltozós műveletet végzünk. És ebben az esetben még csak felvetni sem értelmes a tényezők felcserélhetőségét, nemhogy közlés alapján elfogadtathatnánk! Lehet 5 gombot háromszorozni, de nem lehet a 3-at 5-gombszorozni. Lehet a területszámításnál a $3 \mathrm{~m}^{2}-\mathrm{t}$ 4-szerezni, de nem lehet a $3 \mathrm{~m}$-t 4 méterszerezni! 
A kétféle osztás: az egyenlő részekre való osztás és a bennfoglaló - más néven euklideszi - osztás fogalomépítése, értelmezése is nagy gonddal történt. Amikor a fogalom kidolgozását elkezdjük, tehát konkrét tevékenységeknek feleltetünk meg matematikai tevékenységeket, akkor nincs jogunk összemosni a különbözö tartalmakat! Sőt később is csak a számszerü egyezést fogadhatjuk el. $\mathrm{Az}$ adott szituációkban, szöveges feladatokban való értelmezések akkor is különbözőek!

A kísérleti időszakban még csaknem meglincseltek azért, mert a négyzetet a téglalapok közé mertem sorolni. Hogyan lenne a négyzet téglalap, amelynek csak a szemközti oldalai egyenlők, de a szomszédosak nem? Új szemléletre volt szükség, hogy a fogalmak egymáshoz való viszonya a helyére kerüljön!

Varga Tamás matematikatanításról vallott gondolkodásának egyik alapvetése az volt, hogy egységes a matematika, és ezt az egységességet a kezdetektől látnia kell a fogalmi rendszer épüléséért felelős pedagógusnak. Azt, hogy a különféle témákat csak egységesen alapozva, és minden lehetséges szinten összekapcsolva, összeszöve helyes feldolgozni. A témák esetenként ugyanannak a fogalomnak, összefüggésnek más-más aspektusát világítják meg. Valamely fogalom megközelítéséhez, összefüggés-feltárásához egy másik téma eszközként szolgálhat vagy begyakorlásához nyújt lehetőséget. És az így, spirálisan épülő fogalmi rendszer válik egyre gazdagabbá, egyre mélyebben megérthetővé.

„Az alsós matematika sohasem lehet többé csak számtan” - írta említett cikkében -, bár ,,a számolás a középpontban marad.”

Ennek a gondolatnak az újszerüségét akkor érthetjük meg igazán, ha ismerjük például az 1977-ben 14. kiadását megért 4. osztályos tankönyvet, amely az 1963-tól érvényes tanterv alapján készült. A könyv tartalomjegyzéke így szól:

Ismételjünk!

A tízezres számkör

A téglalap és a négyzet területe

A százezres számkör

Írásbeli osztás kétjegyü osztóval

A milliós számkör

Írásbeli szorzás háromjegyü szorzóval

Írásbeli osztás háromjegyü osztóval

Ismétlö feladatok

Az érdekes feladatok (3 ilyen feladat szerepelt a könyvben!) megoldásai.

És a fejezetek - az első oldalon megjelenő közléseket követően - mindössze a közölt ismeretet gyakorló szám- és szöveges feladatok sokaságát tartalmazzák. Képanyaguk 90-95\%-a a szöveges feladatok tartalmához illesztett illusztráció (pl. szántó traktor, Gagarin és Tyereskova arcképe, épülő házak stb.).

Varga Tamás az első osztálytól egységként épülő matematika fontos területének tekintette a halmazokat, a logikát - anélkül, hogy elmélettel, formalizmussal terhelte volna meg az e témákkal való foglalkozást. A természetes 
szám fogalmának egyik alappilléreként kezelte a halmazokat. Ennél azonban lényegesen szélesebb körü szerepét: az absztrahálás folyamatának csodálatos lehetőségét, a rendszerezés, rendszeralkotás módját is számon tartotta benne, és felhasználta a logikai gondolkodás alapozásának alapvető eszközeként.

A témák között szerepelt az algebra alapozása, relációk, függvények, sorozatok, geometria, mérés, a kombinatorika.

Forradalmi újítás volt, hogy a valószinüséggel is ismerkedhettek a kisdiákok már 6-7 éves koruktól.

Nemcsak a kombinatorikai gondolatok formálásának alkalmát látta a témában. Tehát nemcsak pl. kockadobásokkal, pénzérmékkel, a Galton-deszkával való játékokat, kísérleteket fogalmazott meg, amelyekben a véletlen események bekövetkezésének esélyeit a lehetséges előfordulások számbavétele alapján latolgathatták a gyerekek. De a véletlennek a világunkban jelen lévő óriási szerepét felismerve olyan játékokat, tevékenységeket is kieszelt, amelyekben pl. a rajzszög, vagy a fogpasztás kupak dobásának és különféle helyzetü leesésének megfigyelése játszott szerepet. Vagy az ablak alatt elhaladó jármüvek megfigyelése, jegyzése volt a gyerekek dolga. Tehát, ahol nem voltak egyenlő valószínüségü elemi események.

A tanítás-tanulás egy másik alapvetése, hogy kicsi kortól valódi matematikát kell adnunk a gyerekeknek. Ez az elv nemcsak arra kötelez, hogy a számtanon kívül a matematika többi területével is találkozzanak, és ne szakítsuk szét a matematika összetartozó ágait, vagy hogy sohase tanítsunk olyasmit, amit később módosítani, korrigálni kell. De arra is, hogy ahogyan tanitunk, amiképpen foglalkozunk a gyerekekkel, az is matematikai legyen. Így vált a tanulás-tanitás módszere is tartalmi kérdéssé. Így kaptak előkelő helyet a tantervben a matematikatanulás-matematikatanítás módszerei.

Módszertani törekvéseinek talán legátfogóbb jellemzője, hogy a tanulástanítás folyamatában módosulniuk kellett a szerepeknek. Azt helyezte előtérbe, azt vette alapul, hogy hogyan képes ismereteket szerezni a gyerek, mivel tudja azokat elmélyiteni és bekapcsolni folyamatosan formálódó ismeretrendszerébe, hogyan tudja ezeket alkalmazni.

Tudta, hogy ehhez a gyerekek egyéni és a korosztályt jellemző általános tulajdonságainak, adottságainak, képességeinek mély ismerete, formálódásának minél pontosabb nyomon követése szükséges.

Nem véletlen, hogy az agykutatás, a fejlödéslélektan, a gyermeklélektan legújabb eredményeiről, a nagyvilágban folytatott matematikatanitási kisérletekről naprakész és mélyen átgondolt tudással rendelkezett a tanár úr. És maga is érdeklődéssel kísérte figyelemmel a gyerekek viselkedését, reagálását a kínált helyzetekben.

Öszinte kíváncsisággal hallgatta mások tapasztalatait, tanítási élményeit, és ezeket folyamatosan felhasználta a kísérlet irányításában, tanterv- és taneszközfejlesztő munkájában.

A gyerekek világáról, gondolkodásáról, tanulási lehetőségeiről szerzett nagy tudása alapján térhettünk át a személyes, cselekvö tapasztalatszerzésböl kiinduló 
tanulásra a már régóta általánosan elterjedt, szemléltetésre építő tanításból (ami természetesen már nagy elörelépést jelentett a szavak, mondatok mechanikus memorizáltatásához képest).

Ennek a megfelelö eszközökkel végzett tevékenységnek kettős szerepét tartotta szem elött. Egyrészt a különféle helyzetekben megtapasztalt konkrét tények és a köztük levö sokszinü viszonylatok közös lényegéböl interiorizálódnak a fogalmak. Másrészt az eszközök segítségével külső képsorként megjelenö problémamegoldási folyamat is belsővé, gondolkodási folyamattá válik.

A matematika értelmes tanulásának az is feltétele, hogy utasítások végrehajtása, sokszor ismételt kérdésekre adandó válaszok betanulása helyett foglalkozhassanak a gyerekek akár már óvodás korukban is igazi, gondolkodást építő problémák megoldásával. Olyanokkal, amelyek érdekesek a számukra. Hogy fejükben az üres mondatok helyett a fogalomtartalmak s a köztük levö kapcsolatok formálódjanak ki, hosszú időn át való érleléssel.

A matematikában viszonylag kevés olyan, konvención alapuló ismeret van, amelyben a gyerekek külső tekintélyre szorulnak. Az igazság kritériuma a valósággal való egyezés. Ez teszi olyan alkalmassá e tárgyat arra, hogy benne megtanulják a gyerekek ellenőrizni és értékelni saját munkájukat és társaik munkáját.

A jó tanulói légkör egyik feltétele a tévedés és a vita szabadsága - vallotta Varga Tamás. Ha téves gondolataikat is nyugodtan kimondhatják a gyerekek, és senki nem büntet érte, nem kell szégyenkezni miattuk, akkor kellemesebbé válik a tanulás, és a tanító is megérti, mi okoz gondot. Így a téves gondolat tisztázásához újabb problémákat vethet fel, bevonhatja a többi tanulót is, akik érveléssel, példákkal, saját gondolataik kimondásával segíthetnek.

A tanitó, a tanár szerepe is módosult, kibővült. Nem korlátozódhat arra, hogy az információk kizárólagos forrása, majd az elsajátított ismeretek számon kérője legyen. Feladata a tanulási folyamat átgondolása, a megfelelő eszközök biztosítása, a munka szervezése és szükséges mértékü irányítása, segítése. Még a szerzett ismeretek megfogalmazásában is fontosnak tartotta Varga Tamás a tanulók saját, esetleg pontatlan kifejezéseiből való kiindulást, s ennek tapintatos, értelmező korrigálását.

Minthogy a módszertani kultúra formálása során valóban azt tekintette kiindulópontnak, hogy hogyan tud tanulni a diák, hangsúlyozta a differenciálás fontosságát. Bemutatta azt az akkor számunkra még meglepő tényt, hogy a „kivételesek vannak többen”. Hogy pl. egy 4. osztályban már csak a tanulóknak mindössze nagyjából negyedrésze van mentálisan 4. osztályos szinten.

Az x évesek mentális kora sok vizsgálat eredményéböl leszürve minden x-re normális eloszlású - irta. Ilyen eloszlás esetén 100 pontosan 10 éves gyerek mentális kora egész évre kerekitve: 


\begin{tabular}{|l|c|c|c|c|c|c|c|c|c|}
\hline Mentális életkor & 6 & 7 & 8 & 9 & 10 & 11 & 12 & 13 & 14 \\
\hline A tanulók száma & 1 & 4 & 11 & 21 & 26 & 21 & 11 & 4 & 1 \\
\hline
\end{tabular}

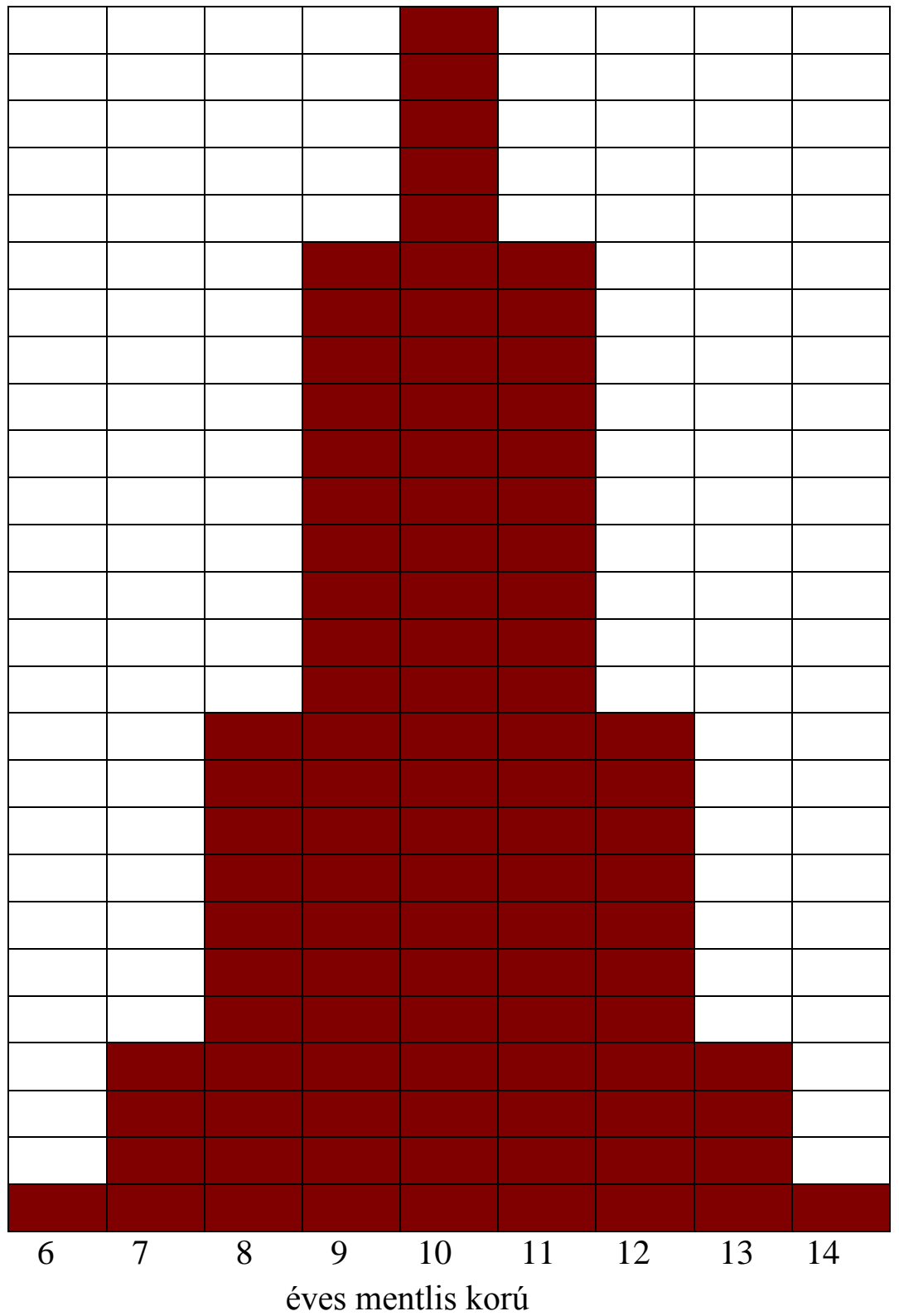

Eszerint a nem 10 éves mentális korúak száma 74. A legalább 2 évvel eltérők száma is 32 !

$\mathrm{S}$ ha felelősek vagyunk azért, hogy mindenki előbbre jusson a maga útján, lépcsősorán, akkor szükséges alkalmazkodnunk ehhez a tényhez. Ugyanis hiába írnánk elö, hogy a 4. osztályosoknak hol kell tartaniuk. Aki még az előző lépcsőfokig nem jutott el, az képtelen továbblépni, aki jócskán túljutott az elöírt szinten, azt unottá, kedvetlenné, érdektelenné teszi a már nem neki való teendő, a már nem neki szóló tananyag, probléma.

Minden lényeges mozzanatára sem tudok kitérni Varga Tamás koncepciójának. Azt azonban még szeretném elmondani, hogy bár fontosnak látta 
a tehetséges tanulók fejlesztését, tevékenységének legfőbb mozgatója az volt, hogy legyen a matematika mindenkié. Hogy váljon a matematikatanulás mindenki számára örömszerzö, alkotó, fejlesztö tevékenységgé.

Szívesen sorolnám most azok nevét, akik munkatársai - óriási munkájának részesei voltak. Soká tartana, nem tehetem. Pedig sokan vannak a jelenleg is ugyanazért az ügyért dolgozó, harcoló kollégák közül és a már elhunytak közül is, akiknek a nem mellékes szerepéről szintén jó lenne egyszer megemlékezni.

Varga Tamás munkájának mai folytatásról tudjuk, hogy a 87-es korrekció után alakuló tantervek, ha nem is változatlanul, de alapelveiben, a tananyag legnagyobb részében megörizték azt a kincset, amelyet ő létrehozott közvetlen és távolabbi munkatársaival együtt. Abból táplálkozott a NAT, a kerettantervek, és a SuliNovában kompetencia alapon épülő tanterv egyaránt. Az éppen formálódó új kerettanterv is sokat merített eredményeiböl. Sőt elmondhatjuk, hogy külföldön is megmaradt az érdeklődés, vannak követői tanterveinknek, tankönyveinknek, Varga Tamás matematikatanításra vonatkozó koncepciójának. Például Finnországban már az ő nevét viselő társaság gondozásában, tankönyveink és taneszközeink felhasználásával sok iskolában igen szép eredménnyel folyik az oktatás.

Nem térhetünk ki a kérdés elöl, hogy az általa megkezdett munkát vajon jól folytatjuk-e mi is, itt Magyarországon. Számba kell vennünk az azóta elért eredményeket, az értékeket, amiket tovább tudtunk fejleszteni. De szembe kell nézni időről időre az oktatásirányítás és a napi gyakorlatok nehézségeivel, esetleges hibáival is, hogy elmondhassuk: közkinccsé válhat a matematika, mert azon dolgozunk - megosztva ötleteinket, pozitív és negatív tapasztalatainkat -, hogy váljon is közkinccsé, mihamarabb. 